\title{
PERENCANAAN PEMBANGUNAN BERBASIS PERTANIAN TANAMAN PANGAN DALAM UPAYA PENANGGULANGAN MASALAH KEMISKINAN
}

\author{
Moch. Arifien ${ }^{1}$, Fafurida ${ }^{2}$, dan Vitradesie Noekent ${ }^{2}$ \\ ${ }^{1}$ Fakultas Ilmu Sosial, Universitas Negeri Semarang \\ 2 Fakultas Ekonomi, Universitas Negeri semarang \\ Kampus Sekaran Gunungpati Semarang \\ E -mail: fafurida@yahoo.com
}

Diterima 10 Februari 2012/ Disetujui 23 September 2012

\begin{abstract}
The main objective of this study is planning for development the agricultural sector, especially food plants in order to improve the local economy. The steps taken is to examine the performance of the agricultural sector in the district, identify potential food plants to be developed in each sub district, construct a hierarchy of centers of social services and economic development, planning the development of agriculture food plants in the district, then describe it in a planning map. The research was conducted in the district Wonosobo. Analysis of the research carried out by using Shift Share analysis, Location Quotient (LQ), and analysis skalogram. The results showed that the highest productivity in agriculture in the district is Wonosobo vegetable plants. Types of plants that can be developed are food plants that have competitive and comparative advantage.
\end{abstract}

Keywords: agricultural development, food plants, performance of the agricultural sector, local economy

\begin{abstract}
Abstrak: Tujuan utama penelitian ini membuat perencanaan untuk pengembangan sektor pertanian, khususnya tanaman pangan demi peningkatan perekonomian daerah. Langkah langkah yang diambil adalah dengan melihat kinerja sektor pertanian di kabupaten, mengidentifikasi komoditas tanaman pangan yang potensial untuk dapat dikembangkan di masingmasing kecamatan di kabupaten, menyusun hierarki pusat-pusat pelayanan sosial dan ekonomi di kabupaten dan menyusun perencanaan pengembangan sektor pertanian sub sektor tanaman pangan di kabupaten yang kemudian digambarkan dalam sebuah peta perencanaan. Penelitian ini dilakukan di kabupaten Wonosobo. Analisis dalam penelitian ini menggunakan analisis Shift Share, Location Quotient (LQ), dan analisis Skalogram. Hasil penelitian menunjukkan bahwa produktivitas tertinggi dalam pertanian di kabupaten Wonosobo adalah tanaman sayuran. Jenis komoditas tanaman yang dapat dikembangkan adalah komoditas tanaman pangan yang memiliki keunggulan kompetitif dan komparatif.
\end{abstract}

Kata kunci: pembangunan pertanian, tanaman pangan, kinerja sektor pertanian, ekonomi daerah

\section{PENDAHULUAN}

Upaya pengembangan wilayah (regional development) secara terpadu melalui penyusunan rencana tata ruang harus diarahkan pada pemecahan masalah utama di daerah tersebut, dalam hal tingkat kesejahteraan dan pertumbuhan ekonomi. Adanya perbedaan, baik alamiah maupun buatan antardaerah dalam suatu wilayah, menyebabkan adanya perbedaan dalam peluang untuk tumbuh dan berkembang.

Kabupaten Wonosobo merupakan daerah yang memiliki jumlah penduduk miskin terbanyak di provinsi Jawa Tengah (BPS, 2009). Dilihat dari nilai PDRB per kapitanya kabupaten 
Wonosobo juga termasuk daerah yang memiliki PDRB per kapita terendah. Untuk itu diperlukan suatu upaya untuk meningkatkan perekonomian daerah agar dapat menyelesaikan permasalahan tersebut. Kunci keberhasilan suatu pembangunan adalah perencanaan yang tepat. Perencanaan pada hakekatnya harus didasarkan pada masalah, kebutuhan dasar dan potensi wilayah agar pembangunan yang dilakukan tepat guna dan tepat sasaran sehingga mampu meningkatkan perekonomian daerah. Wonosobo merupakan wilayah yang memiliki basis sektor pertanian. Daerahnya yang terletak di dataran tinggi membuat pertanian di wilayah ini tumbuh dengan baik. Pemanfaatan sektor unggulan untuk peningkatan perekonomian daerah dapat dilakukan dengan membuat perencanaan yang berbasis potensi ekonomi lokal dan salah satunya adalah pertanian tanaman pangan.

Tujuan utama penelitian ini adalah menyusun perencanaan dalam upaya pengembangan sektor pertanian khususnya tanaman pangan demi peningkatan perekonomian daerah dengan cara melihat performance (kinerja) sektor pertanian di kabupaten Wonosobo, mengidentifikasi komoditas tanaman pangan yang potensial untuk dapat dikembangkan di masingmasing kecamatan di kabupaten Wonosobo, menyusun hierarki pusat-pusat pelayanan sosial dan ekonomi di kabupaten Wonosobo dan menyusun perencanaan pengembangan sektor pertanian sub sektor tanaman pangan di kabupaten Wonosobo yang kemudian digambarkan dalam sebuah peta perencanaan.

Penelitian Terdahulu. Penelitian Terdahulu yang mendasari penelitian ini di antaranya adalah, penelitian yang dilakukan oleh Syafruddin, Agustinus N. Kairupan, A. Negara, dan J. Limbongan (2004) dalam penelitiannya yang berjudul "Penataan Sistem Pertanian dan Penetapan Komoditas Unggulan Berdasarkan Zona Arkeologi di Sulawesi Tengah". Dalam penelitian ini dikemukakan bahwa sistem pertanian yang efisien, berproduksi tinggi, dan berkelanjutan dapat dicapai antara lain dengan memanfaatkan sumber daya lahan berdasarkan karakteristik, kemampuan, dan kesesuaiannya. Lahan sebagai modal dasar dan faktor penentu utama dalam sistem produksi pertanian perlu dijaga agar tidak mengalami kerusakan. Oleh karena itu, penataan sistem pertanian dan penetapan komoditas unggulan pada setiap wilayah kabupaten perlu dilakukan agar produksi yang dihasilkan tetap tinggi dan dapat bersaing di pasaran, baik lokal maupun internasional. Konsep sistem pakar dapat digunakan dalam menata sistem pertanian dan menetapkan komoditas unggulan. Hasil delineasi peta zona agroekologi wilayah Sulawesi Tengah skala 1:250.000 didapatkan tujuh zona utama, empat sistem pertanian, dan beberapa jenis tanaman alternatif. Komoditas unggulan juga telah ditetapkan untuk masingmasing wilayah kabupaten, yaitu kakao, jagung, bawang merah, sapi potong, serta perikanan laut.

Kedua adalah penelitian Gustavo Anríquez and Kostas Stamoulis (2007) yang menguji hubungan antara pedesaan dan kemiskinan, dan peran sektor pertanian yang dapat digunakan dalam pembangunan pedesaan, pengurangan kemiskinan, dan pengembangan secara keseluruhan. Penelitian ini menjelaskan bagaimana pada kondisi-kondisi tertentu strategi pengembangan wilayah dapat berhasil baik, tetapi di sisi lain pada kondisi-kondisi tertentu, terutama pada negara-negara yang tingkat pembangunannya rendah seperti pedesaan, pertanian merupakan titik awal untuk pembangunan pedesaan. Beberapa teori yang mendasari penelitian ini adalah:

Teori Basis Ekonomi. Teori ini menyatakan bahwa pertumbuhan suatu wilayah sangat tergantung kepada kemampuan wilayah itu untuk mengekspor barang atau jasa. Menurut North (1975) dalam Temenggung (1999), pertumbuhan wilayah dalam jangka panjang tergantung industri ekspornya. Kekuatan utama pertumbuhan wilayah adalah permintaan dari luar akan barang dan jasa yang dihasilkan dan diekspor. Permintaan dari luar wilayah mempengaruhi penggunaan modal, tenaga kerja, dan teknologi untuk menghasilkan ekspor sehingga terbentuk keterkaitan ekonomi baik ke belakang maupun kedepan. Menurut Hoover (1984), pertumbuhan beberapa sektor basis akan menentukan pembangunan daerah secara keseluruhan, sementara sektor non basis hanya merupakan 
konsekuensi-konsekuensi dari pembangunan daerah. Barang dan jasa dari sektor basis yang diekspor akan menghasilkan pendapatan bagi daerah serta meningkatkan konsumsi dan investasi. Peningkatan pendapatan tidak hanya menyebabkan kenaikan permintaan terhadap sektor basis, tetapi juga akan menaikan permintaan terhadap sektor non basis berarti juga mendorong kenaikan investasi sektor non basis. Penggunaan teori ini dalam suatu studi dimaksudkan untuk mengidentifikasi sektor-sektor pembangunan yang termasuk sektor basis maupun non basis pada suatu daerah.

Perencanaan Pusat Pelayanan. Konsep pusat pelayanan ditelaah dan diadaptasi dari berbagai teori. Teori-teori tersebut yaitu teori pusat pertumbuhan dan kutub pertumbuhan, teori tempat sentral, spread-backwash effect, dan trickling down dan polarization effect.

(1) Growth Pole (Kutub Pertumbuhan) dan Pusat Pertumbuhan. Teori Perroux (1970) yang dikenal dengan istilah pusat pertumbuhan merupakan teori yang menjadi dasar dari strategi kebijaksanaan pembangunan industri daerah yang banyak diterapkan di berbagai negara dewasa ini. Perroux mengatakan pertumbuhan tidak muncul di berbagai daerah pada waktu yang sama. Pertumbuhan hanya terjadi di beberapa tempat yang disebut pusat pertumbuhan. Inti dari teori Pusat Pertumbuhan adalah sebagai berikut:

(a) Dalam proses pembangunan akan timbul industri unggulan yang merupakan industri penggerak utama dalam pembangunan ekonomi daerah. Karena keterkaitan antarindustri sangat erat, maka perkembangan industri unggulan akan mempengaruhi perkembangan industri lain yang berhubungan erat dengan industri tersebut.

(b) Pemusatan industri pada suatu daerah akan mempercepat pertumbuhan perekonomian, karena pemusatan industri akan menciptakan pola konsumsi yang berbeda antardaerah sehingga perkembangan industri di daerah tersebut akan mempengaruhi perkembangan daerah-daerah lainnya.

(c) Perekonomian merupakan gabungan dari sistem industri yang relatif aktif (industri unggulan) dengan industri-industri yang relatif pasif yaitu industri yang tergantung dari industri unggulan atau pusat pertumbuhan. Daerah yang relatif maju atau aktif akan mempengaruhi daerah-daerah yang relatif pasif.

(2) Hierarki Pusat-Pusat Wilayah dan Pusat Pelayanan. Timbulnya pusat-pusat wilayah disebabkan oleh beberapa faktor sebagai berikut:

(a) Faktor Lokasi Ekonomi. Letak suatu wilayah yang strategis menyebabkan suatu wilayah dapat menjadi suatu pusat. Sebagai contoh adalah Singapura.

(b) Faktor ketersediaan Sumber Daya. Ketersediaan sumber daya alam pada suatu wilayah akan menyebabkan wilayah tersebut menjadi pusat. Sebagai contoh adalah Medan.

(c) Kekuatan Aglomerasi. Kekuatan aglomerasi terjadi karena ada sesuatu yang mendorong kegiatan ekonomi sejenis untuk mengelompok pada suatu lokasi karena adanya sesuatu keuntungan. Selanjutnya akan menyebabkan timbulnya pusat-pusat wilayah. Sebagai contoh yang terjadi hampir di seluruh kota-kota di Indonesia.

(d) Faktor Investasi Pemerintah. Ketiga faktor-faktor diatas menyebabkan timbulnya pusat-pusat wilayah secara alamiah. Sedangkan faktor investasi pemerintah merupakan sesuatu yang sengaja dibuat. Sebagai contoh adalah kota Palangkaraya, ibukota provinsi Kalimantan Tengah.

Pada dasarnya pusat wilayah mempunyai hierarki. Hierarki dari suatu pusat ditentukan oleh beberapa faktor, yaitu: Jumlah penduduk yang bermukim pada pusat tersebut; Jumlah fasilitas pelayanan umum yang tersedia; dan Jumlah jenis fasilitas pelayanan umum yang tersedia.

Identifikasi dari pusat-pusat pelayanan mempunyai beberapa tujuan yaitu sebagai berikut: Mengidentifikasikan pusat-pusat pelayanan dan daerah pelayanan pada tingkat yang berbeda; Penentuan dari fasilitas infrastruktur pokok untuk memuaskan kebutuhan beragam sektor dari penduduk; dan Pengintegrasian atau pengelompokan pelayanan pada tingkat yang berbeda dan penentuan dari keterkaitan atau jaringan jalan untuk mengembangkan aksesibilitas dan efisiensi. 


\section{METODE PENELITIAN}

Jenis data yang digunakan dalam penelitian ini adalah kombinasi antara data sekunder dan data primer. Data sekunder diperoleh dari berbagai sumber yaitu BPS kabupaten Wonosobo, BAPPEDA kabupaten Wonosobo serta instansi yang terkait lainnya. Sedangkan data primer dilakukan dengan teknik wawancara dengan pihak pembuat perencanaan daerah, dalam hal ini adalah pihak BAPPEDA kabupaten Wonosobo, diskusi dengan kelompok-kelompok petani di tiap kecamatan di kabupaten Wonosobo serta pengamatan lapangan secara langsung.

Alat analisis yang digunakan adalah dengan analisis Shift Share, Location Quotient (LQ) dan analisis Skalogram. Analisis Shift Share digunakan untuk mengetahui komoditas-komoditas tanaman pangan yang memiliki keunggulan kompetitif di tiap kecamatan. Sedangkan dari hasil analisis Location Quotient (LQ) dapat diketahui komoditas-komoditas tanaman pangan yang memiliki keunggulan komparatif di tiap kecamatan. Dari hasil analisis Shift Share dan Location Quotient (LQ) akan diketahui komoditas-komoditas tanaman pangan yang dapat dikembangkan di tiap kecamatan. Komoditas tanaman pangan yang dapat dikembangkan di tiap kecamatan adalah komoditas tanaman pangan yang memiliki keunggulan kompetitif dan keunggulan komparatif atau salah satunya. Sedangkan analisis Skalogram digunakan untuk menentukan hierarki pusat pelayanan yang nantinya juga digunakan sebagai pedoman pendirian industri pengolahan.

\section{HASIL DAN PEMBAHASAN}

\section{Kinerja Sektor Pertanian di kabupaten Wonosobo}

Jika dilihat dari penggunaan lahan di kabupaten Wonosobo, mayoritas lahan di daerah tersebut banyak digunakan sebagai kebun dan sawah. Penggunaan lahan untuk kebun mencapai 43 persen dari total luas wilayah kabupaten Wonosobo atau seluas 42.083 Ha. Sedangkan penggunaan lahan untuk sawah mencapai 17 persen atau seluas 17.174 Ha. Melihat gambaran tersebut dapat dilihat mayoritas penggunaan lahan di kabupaten Wonosobo, digunakan oleh sektor pertanian.

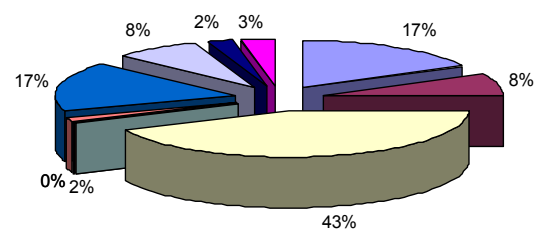

\begin{tabular}{|llll|}
\hline$\square$ Sawah & $\square$ Bangunan & $\square$ Kebun & $\square$ Padang Rumput $\square$ Kolam \\
$\square$ Waduk & $\square$ Hutan Negara & $\square$ Hutan Rakyat & $\square$ Perkebunan $\quad \square$ Lain-lain \\
\hline
\end{tabular}

\section{Gambar 1. Jenis penggunaan lahan di} Kabupaten Wonosobo

Dari lima sub sektor pertanian yang ada, yang memiliki andil terbesar dalam perekonomian kabupaten Wonosobo adalah pertanian tanaman pangan dengan komoditasnya meliputi tanaman padi dan palawija, tanaman sayuran dan tanaman buah-buahan. Pada tahun 2009, produksi padi sawah mengalami peningkatan sebesar 41 ton meskipun luas panennya mengalami penurunan 946 hektar (3,14 persen). Berbeda dengan padi sawah, produksi padi gogo meningkat dari 1524 ton pada tahun 2008 menjadi 2982 ton $(95,67$ persen) dengan luas panen meningkat sebesar 166,29 persen. Hal ini berarti rata-rata produksi padi sawah per hektar mengalami peningkatan, sedangkan ratarata produksi per hektar padi gogo mengalami penurunan pada tahun 2008. Secara keseluruhan produktivitas padi mencapai 162.955 ton dengan luas panen 30.071 Ha. Peningkatan produktivitas padi tidak terlepas dari usaha pemerintah dalam upaya meningkatkan ketahanan pangan seperti bantuan benih, pupuk, dan sarana pertanian serta didukung oleh tenaga penyuluh pertanian di lapangan.

Produktivitas tertinggi dalam pertanian di kabupaten Wonosobo adalah tanaman sayuran yang mencapai 176.981 ton dengan luas panen 13.383 Ha. Sedangkan untuk tanaman buahbuahan dalam 4.106 .391 pohon, mampu menghasilkan 124.661 ton. 
Tabel 1. Luas Panen dan Produktivitas Tiap Jenis Tanaman Pangan di Kabupaten Wonosobo Tahun 2009

\begin{tabular}{lcc}
\hline \multicolumn{1}{c}{ Jenis Tanaman } & $\begin{array}{c}\text { Luas Panen } \\
\text { (Ha / pohon) }\end{array}$ & $\begin{array}{c}\text { Produktivitas } \\
\text { (Ton) }\end{array}$ \\
\hline Padi & $30.071 \mathrm{Ha}$ & 162.955 \\
Jagung & $32.390 \mathrm{Ha}$ & 136.683 \\
Ubi Kayu & $6.204 \mathrm{Ha}$ & 147.122 \\
Ubi Jalar & $713 \mathrm{Ha}$ & 13.962 \\
Kacang-kacangan & $214 \mathrm{Ha}$ & 277 \\
Sayuran & $13.383 \mathrm{Ha}$ & 176.981 \\
buah-buahan & 4.106 .391 pohon & 124.661 \\
\hline
\end{tabular}

Sumber: Buku Wonosobo dalam Angka, 2009

Sumber makanan pokok selain padi di kabupaten Wonosobo adalah jagung dan ubi kayu. Pada tahun 2009 produksi jagung dan ubi kayu mengalami peningkatan. Produksi jagung meningkat sebesar 5 persen dengan luas panen yang hanya meningkat 2,33 persen, bahkan produksi ubi kayu meningkat 9,05 persen meskipun terjadi penurunan luas panen sebesar 10,31 persen. Peningkatan produksi jagung dan ubi kayu sangat menunjang pemerintah dalam rangka mencapai ketahanan pangan.

Produksi tanaman sayuran pada tahun 2009 mengalami peningkatan yang cukup signifikan kecuali wortel dan kacang merah. Tanaman sayuran utama di kabupaten Wonosobo adalah kobis, petai/sawi, kentang, daun bawang, tomat, cabai, wortel, dan buncis. Daerah penghasil sayuran yang utama di kabupaten Wonosobo adalah kecamatan Kalikajar, Kertek, Garung, dan Kejajar.

Untuk tanaman buah-buahan, salak dan pisang banyak dihasilkan di kabupaten Wonosobo. Namun demikian kedua komoditi ini tidak tersebar merata di semua kecamatan. Pisang lebih banyak dihasilkan dari kecamatan Kaliwiro dan Selomerto, sedangkan salak lebih banyak dihasilkan dari kecamatan Leksono, Sukoharjo dan Kalikajar.

Komoditas tanaman pangan unggulan yang potensial untuk dapat dikembangkan di masing-masing kecamatan di kabupaten Wonosobo

Untuk mengidentifikasi komoditas tanaman pangan unggulan yang potensial untuk dapat dikembangkan di masing-masing kecamatan di kabupaten Wonosobo pada penelitian ini didasarkan pada komoditas yang memiliki keunggulan kompetitif dan komparatif, atau memiliki keunggulan kompetitif atau komparatif saja. Yang dimaksud dengan keunggulan kompetitif adalah komoditas yang mampu bersaing dengan komoditas yang sama dengan daerah lain, hal ini dapat diukur dengan melihat nilai komponen Cij (komponen keunggulan kompetitif) pada analisis Shift Share. Jika nilai Cij pada analisis Shift Share bernilai positif, maka komoditas tersebut memiliki keunggulan kompetitif. Sedangkan suatu komoditas dikatakan memiliki keunggulan komparatif apabila hasil produksi dari suatu komoditas di suatu daerah hasilnya dapat memenuhi kebutuhan dalam daerah dan sisanya masih bisa di ekspor ke luar daerah, hal ini bisa dilihat dari hasil analisis Location Quotient (LQ). Jika nilai analisis Location Quotient (LQ) pada suatu komoditas di suatu daerah bernilai lebih besar dari satu (LQ>1) maka komoditas tersebut bisa dikatakan memiliki keunggulan komparatif.

Dalam penelitian ini, komoditas yang dikembangkan di tiap kecamatan adalah komoditas yang merupakan komoditas unggulan dan komoditas potensial. Dikatakan komoditas unggulan apabila komoditas di suatu daerah memiliki keunggulan kompetitif dan komparatif. Sedangkan dikatakan potensial apabila memiliki keunggulan kompetitif atau keunggulan komparatif saja.

Komoditas Tanaman Pangan yang Memiliki Keunggulan Kompetitif

Dari hasil analisis Shift Share diperoleh hasil komoditas tanaman pangan yang memiliki keunggulan kompetitif di tiap kecamatan di kabupaten Wonosobo adalah sebagai berikut: Kecamatan Wadaslintang: padi, jagung, ubi kayu, kacang-kacangan, dan sayuran. Kecamatan Kepil: kacang-kacangan dan buah-buahan. 
Kecamatan Sapuran: padi, jagung, ubi kayu dan sayuran. Kecamatan Kalibawang: jagung, ubi kayu dan buah-buahan. Kecamatan Kaliwiro: jagung dan buah-buahan. Kecamatan Leksono: jagung, ubi kayu, sayuran dan buahbuahan. Kecamatan Sukoharjo: (-). Kecamatan Selomerto: padi, jagung, ubi kayu, ubi jalar, kacang-kacangan, sayuran dan buah-buahan. Kecamatan Kalikajar: jagung, ubi jalar dan buah-buahan. Kecamatan Kertek: (-). Kecamatan Wonosobo: sayuran. Kecamatan Watumalang: padi, ubi jalar, sayuran dan buah-buahan. Kecamatan Mojotengah: padi, ubi kayu, ubi jalar, sayuran dan buah-buahan. Kecamatan Garung: padi, ubi jalar dan sayuran. Kecamatan Kejajar: jagung, ubi kayu dan buah buahan.

Komoditas Tanaman Pangan yang Memiliki Keunggulan Komparatif

Dari hasil analisis Location Quotient masingmasing kecamatan di kabupaten Wonosobo, maka diperoleh hasil seperti yang tercantum pada Tabel 2.

Dari hasil analisis LQ di atas dapat dilihat komoditas tanaman pangan yang memiliki keunggulan komparatif berdasarkan kriteria LQ, yaitu jika nilai LQ>1. Sebaliknya, jika nilai $\mathrm{LQ}<1$, maka komoditas tersebut tidak memiliki keunggulan komparatif. Untuk lebih rincinya di bawah ini akan diuraikan komoditas tanaman pangan yang memiliki keunggulan komparatif di masing-masing kecamatan di kabupaten
Wonosobo.

Kecamatan Wadaslintang: padi, jagung, ubi kayu, kacang-kacangan dan buah-buahan. Kecamatan Kepil: padi, jagung, ubi kayu, kacang-kacangan dan buah-buahan. Kecamatan Sapuran: padi, jagung, ubi kayu, kacangkacangan dan sayuran. Kecamatan Kalibawang: padi, jagung, ubi kayu dan kacangkacangan. Kecamatan Kaliwiro: padi, Kecamatan Leksono: buah-buahan. Kecamatan Sukoharjo: padi, ubi kayu dan buah-buahan. Kecamatan Selomerto: padi, kacang-kacangan, dan buah-buahan. Kecamatan Kalikajar: padi, jagung, ubi jalar, dan sayuran. Kecamatan Kertek: padi, jagung, dan sayuran. Kecamatan Wonosobo: padi dan sayuran. Kecamatan Watumalang: padi, jagung, ubi kayu, ubi jalar dan sayuran. Kecamatan Mojotengah: padi, jagung, ubi kayu, ubi jalar, dan sayuran. Kecamatan Garung: ubi kayu, ubi jalar, dan sayuran. Kecamatan Kejajar: sayuran.

Komoditas Tanaman Pangan Unggulan yang Dapat Dikembangkan di Masing Masing Kecamatan di Kabupaten Wonosobo

Komoditas tanaman pangan yang dapat dikembangkan di masing-masing kecamatan di kabupaten Wonosobo ditentukan berdasarkan hasil analisis Shift Share dan LQ. Komoditas tanaman pangan yang dapat dikembangkan adalah komoditas tanaman pangan yang memiliki keunggulan kompetitif dan keunggulan komparatif

Tabel 2. Hasil Analisis LQ Berdasar Luas Panen Komoditas Tanaman Pangan Masing-masing Kecamatan di Kabupaten Wonosobo Tahun 2009

\begin{tabular}{clccccccc}
\hline No & Kecamatan & Padi & Jagung & Ubi Kayu & Ubi Jalar & Kacang-kacangan & Sayuran & Buah-buahan \\
\hline 1 & Wadaslintang & 6,72 & 1,59 & 5,20 & 0,00 & 36,01 & 0,15 & 1,30 \\
2 & Kepil & 5,73 & 7,85 & 2,01 & 0,66 & 4,87 & 0,41 & 1,00 \\
3 & Sapuran & 1,88 & 2,50 & 1,07 & 0,41 & 2,48 & 2,40 & 0,08 \\
4 & Kalibawang & 3,42 & 12,71 & 10,65 & 0,00 & 3,20 & 0,40 & 0,31 \\
5 & Kaliwiro & 1,14 & 0,17 & 0,71 & 0,00 & 0,00 & 0,00 & 2,22 \\
6 & Leksono & 0,29 & 0,08 & 0,41 & 0,31 & 0,30 & 0,03 & 2,28 \\
7 & Sukoharjo & 1,21 & 0,99 & 1,47 & 0,00 & 0,00 & 0,02 & 2,10 \\
8 & Selomerto & 2,12 & 0,28 & 0,57 & 0,62 & 2,06 & 0,46 & 1,77 \\
9 & Kalikajar & 1,26 & 3,38 & 0,33 & 4,03 & 0,32 & 1,77 & 0,59 \\
10 & Kertek & 3,96 & 3,32 & 0,05 & 0,71 & 0,00 & 1,84 & 0,38 \\
11 & Wonosobo & 3,61 & 0,54 & 0,42 & 0,00 & 0,00 & 2,02 & 0,41 \\
12 & Watumalang & 3,76 & 8,81 & 5,62 & 3,46 & 0,00 & 1,09 & 0,28 \\
13 & Mojotengah & 4,41 & 5,13 & 5,48 & 5,12 & 0,00 & 1,55 & 0,09 \\
14 & Garung & 0,38 & 0,63 & 4,30 & 7,02 & 0,00 & 2,41 & 0,04 \\
15 & Kejajar & 0,00 & 0,11 & 0,00 & 0,03 & 0,00 & 2,92 & 0,01 \\
\hline
\end{tabular}

Sumber: Data diolah, 2011 
Tabel 3. Komoditas Tanaman Pangan Unggulan

\begin{tabular}{|c|c|c|c|c|c|c|c|c|c|c|c|c|c|c|c|}
\hline \multirow[t]{2}{*}{ No } & \multirow[t]{2}{*}{ Kecamatan } & \multicolumn{2}{|c|}{ Padi } & \multicolumn{2}{|c|}{ Jagung } & \multicolumn{2}{|c|}{ Ubi Kayu } & \multicolumn{2}{|c|}{ Ubi Jalar } & \multicolumn{2}{|c|}{$\begin{array}{l}\text { Kacang - } \\
\text { kacangan }\end{array}$} & \multicolumn{2}{|c|}{ Sayuran } & \multicolumn{2}{|c|}{$\begin{array}{c}\text { Buah- } \\
\text { buahan }\end{array}$} \\
\hline & & SS & LQ & SS & LQ & SS & LQ & SS & LQ & SS & LQ & SS & LQ & SS & LQ \\
\hline 1 & Wadaslintang & + & + & + & + & + & + & - & - & + & + & + & - & - & + \\
\hline 2 & Kepil & - & + & - & + & - & + & - & - & + & + & - & - & + & + \\
\hline 3 & Sapuran & + & + & + & + & + & + & - & - & - & + & + & + & - & - \\
\hline 4 & Kalibawang & - & + & + & + & + & + & - & - & - & + & - & - & + & - \\
\hline 5 & Kaliwiro & - & + & + & - & - & - & - & - & - & - & - & - & + & - \\
\hline 6 & Leksono & - & - & + & - & + & - & - & - & - & - & + & - & + & + \\
\hline 7 & Sukoharjo & - & + & - & - & - & + & - & - & - & - & - & - & - & + \\
\hline 8 & Selomerto & + & + & + & - & + & - & + & - & + & + & + & - & + & + \\
\hline 9 & Kalikajar & - & + & + & + & - & - & + & + & - & - & - & + & + & - \\
\hline 10 & Kertek & - & + & - & + & - & - & - & - & - & - & - & + & - & - \\
\hline 11 & Wonosobo & - & + & - & - & - & - & - & - & - & - & + & + & - & - \\
\hline 12 & Watumalang & + & + & - & + & - & + & + & + & - & - & + & + & + & - \\
\hline 13 & Mojotengah & + & + & - & + & + & + & + & + & - & - & + & + & + & - \\
\hline 14 & Garung & + & - & - & - & - & + & + & + & - & - & + & + & - & - \\
\hline 15 & Kejajar & - & - & + & - & + & - & - & - & - & - & - & + & + & - \\
\hline
\end{tabular}

Sumber: Data diolah, 2011

atau salah satunya. Maka dari hasil analisis Shift Share dan LQ yang telah diuraikan di atas dapat dibuat tabel komoditas tanaman pangan yang memiliki keunggulan komperitif dan komparatif dalam Tabel 3.

Dari Tabel 3 dapat dilihat komoditas tanaman pangan yang dapat dikategorikan menjadi beberapa kriteria, yaitu: (1) komoditas unggulan, yang termasuk komoditas unggulan adalah komoditas yang memiliki keunggulan kompetitif dan komparatif (SS dan LQ bertanda positif), (2) komoditas potensial, yang termasuk dalam komoditas ini adalah komoditas yang memiliki keunggulan kompetitif atau keunggulan komparatif ( SS atau LQ bertanda positif), 3) komoditas terbelakang, yaitu komoditas yang tidak memiliki keunggulan kompetitif ataupun komparatif (SS dan LQ bertanda negatif ).

Komoditas tanaman pangan yang dapat dikembangkan di tiap kecamatan adalah komoditas unggulan dan potensial yaitu komoditas tanaman pangan yang memiliki keunggulan kompetitif dan komparatif atau salah satunya. Jadi dari Tabel 3 dapat disimpulkan komoditaskomoditas tanaman pangan yang dapat dikembangkan di tiap kecamatan di kabupaten Wonosobo adalah sebagai berikut:

Kecamatan Wadaslintang: padi, jagung, ubi kayu, kacang-kacangan, sayuran dan buah- buahan. Kecamatan Kepil: padi, jagung, ubi kayu, kacang-kacangan dan buah-buahan. Kecamatan Sapuran: padi, jagung, ubi kayu, kacang-kacangan dan sayuran. Kecamatan Kalibawang: padi, jagung, ubi kayu, kacangkacangan, dan buah-buahan. Kecamatan Kaliwiro: padi, jagung, dan buah-buahan. Kecamatan Leksono: jagung, ubi kayu, sayuran, dan buah-buahan. Kecamatan Sukoharjo: padi, ubi kayu, dan buah-buahan. Kecamatan Selomerto: padi, jagung, ubi kayu, ubi jalar, kacang-kacangan, sayuran, dan buah-buahan. Kecamatan Kalikajar: padi, jagung, ubi jalar, sayuran, dan buah-buahan.Kecamatan Kertek: padi, jagung, dan sayuran. Kecamatan Wonosobo: padi dan sayuran. Kecamatan Watumalang: padi, jagung, ubi kayu, ubi jalar, sayuran, dan buahbuahan. Kecamatan Mojotengah: padi, jagung, ubi kayu, ubi jalar, sayuran, dan buah-buahan. Kecamatan Garung: padi, ubi kayu, ubi jalar, dan sayuran. Kecamatan Kejajar: jagung, ubi kayu, sayuran, dan buah-buahan.

\section{Hierarki pusat-pusat pelayanan sosial dan ekonomi di Kabupaten Wonosobo}

Berdasarkan hasil analisis Skalogram dapat dilihat kecamatan yang memiliki kelengkapan infrastruktur tinggi adalah kecamatan Kepil, Kertek, Wadaslintang, Wonosobo dan Kaliwiro dengan jumlah unit fasilitas umum sebanyak 
595, 509, 508, 491 dan 424. Sedangkan kecamatan yang memiliki jumlah unit fasilitas umum rendah yaitu kecamatan Kejajar, Selomerto, Leksono, Kalibawang dan Sukoharjo dengan jumlah unit sebanyak 329, 298, 254, 250 dan 237 unit.

Dalam penggolongan pusat wilayah, digolongkan dalam tiga hierarki yaitu hierarki I, yang tergolong dalam hierarki ini adalah daerah-daerah yang infrastrukturnya berkembang yaitu kecamatan Kepil, Kertek, Wadaslintang, Wonosobo dan Kaliwiro. Hierarki II yaitu daerah-daerah yang infrastrukturnya moderat (tidak berkembang tetapi juga tidak terbelakang) yaitu kecamatan Kalikajar, Sapuran, Garung, Watumalang dan Mojotengah. Sedangkan hierarki III yaitu daerah-daerah yang infrastrukturnya terbelakang yaitu kecamatan Kejajar, Selomerto, Leksono, Kalibawang, dan Sukoharjo.

Kecamatan yang berpotensi dikembangkan sebagai pusat pelayanan di kabupaten Wonosobo meliputi kecamatan yang berada dalam hierarki I yaitu kecamatan Kepil, Kertek, Wadaslintang, Wonosobo dan Kaliwiro. Kecamatan sebagai pusat pelayanan utama terletak pada kecamatan yang memiliki rangking satu atau kecamatan yang memiliki jumlah fasilitas umum dan infrastruktur paling tinggi yaitu kecamatan Kepil dengan jumlah unit sebesar 595.

Kecamatan Kejajar, Selomerto, Leksono, Kalibawang, dan Sukoharjo merupakan kecamatan yang kekurangan fasilitas pelayanan sosial dan ekonomi, sehingga pembangunan pusat-pusat pelayanan sosial dan ekonomi di kelima kecamatan tersebut perlu diprioritaskan dan perlu diadakan perbaikan dan pengadaan fasilitas umum atau infrastruktur agar menjadi daerah/kecamatan yang mendukung dalam pengembangan ekonomi dan wilayah tersebut.

\section{Perencanaan pengembangan sektor perta- nian sub sektor tanaman pangan di kabu- paten Wonosobo}

Berdasarkan hasil analisis Shift Share dan Location Quotient, terlihat bahwa komoditas-komoditas unggulan di kabupaten Wonosobo membentuk suatu cluster. Komoditas padi terdapat di kabupaten Wonosobo bagian tengah dan selatan. Komoditas tanaman jagung menyebar di hampir seluruh kabupaten Wonosobo. Ubi Kayu terdapat di daerah bagian utara dan selatan. Ubi rambat di bagian utara. Komoditas tanaman kacang-kacangan terdapat di bagian selatan kabupaten Wonosobo. Sayuran terdapat di bagian utara dan buah-buahan di bagian barat dan selatan kabupaten Wonosobo.

Dalam setiap cluster dari komoditas tanaman pangan akan didirikan industri pengolahan, sedangkan wilayah lainnya sebagai daerah pendukung (hinterland) akan berfungsi sebagai penyedia input industri pengolahan tersebut. Industri pengolahan perlu dibangun pada masing-masing cluster komoditas unggulan untuk menampung produksi yang dihasilkan. Adanya industri pengolahan, komoditas yang dihasilkan langsung dapat diproses menjadi produkproduk turunannya yang mempunyai nilai jual yang lebih baik daripada dijual dalam keadaan belum diolah.

Pemilihan lokasi industri pengolahan tanaman pangan berdasarkan asumsi bahwa investor akan masuk ke suatu daerah apabila infrastruktur di daerah tersebut baik. Hal ini dapat ditunjukkan dari nilai skalogram untuk masing-masing kecamatan. Semakin tinggi jumlah unit fasilitas ekonomi dan sosial dari suatu kecamatan menunjukkan bahwa semakin lengkap infrastruktur yang telah dimiliki oleh kecamatan tersebut dan sebaliknya. Dalam hal ini nilai tingkat kelengkapan fasilitas sosial dan ekonomi dapat dilihat dari ranking pada analisis skalogram. Selain berdasarkan tingkat kelengkapan fasilitas sosial ekonomi, untuk menentukan lokasi pendirian industri pengolahan juga didasarkan pada teori lokasi. Dalam teori lokasi dinyatakan bahwa untuk menentukan lokasi pendirian industri terdapat dua orientasi. Yang pertama adalah orientasi pasar dan yang kedua orientasi sumberdaya. Karena pada sebagian besar produksi yang berbahan baku hasil pertanian biasanya terjadi weight loosing activity, maka rekomendasi penentuan lokasi industri adalah di wilayah sumberdaya atau lokasi bahan baku. Berdasarkan pada teori tersebut, pada penelitian ini rekomendasi lokasi pendirian industri pasti di daerah sumberdaya dan yang memiliki kelengkapan fasilitas sosial dan 
Tabel 4. Arah Pengembangan Komoditas Tanaman Padi

\begin{tabular}{clcccc}
\hline No & \multicolumn{1}{c}{ Kecamatan } & $\begin{array}{c}\text { Rangking } \\
\text { Skalogram }\end{array}$ & \multicolumn{2}{c}{ Keunggulan } & Arah Pengembangan \\
\cline { 3 - 5 } & & 3 & + & LQ & \\
\hline 1 & Wadaslintang & 1 & - & + & Sentra produksi \\
2 & Kepil & 7 & + & + & Penggilingan padi \\
3 & Sapuran & 14 & - & + & Sentra produksi \\
4 & Kalibawang & 5 & - & + & Sentra produksi \\
5 & Kaliwiro & 15 & - & + & Sentra produksi \\
6 & Sukoharjo & 12 & + & + & Sentra produksi \\
7 & Selomerto & 6 & - & + & Sentra produksi \\
8 & Kalikajar & 2 & - & + & Sentra produksi \\
9 & Kertek & 4 & - & + & Penggilingan padi \\
10 & Wonosobo & 9 & + & + & Sentra produksi \\
11 & Watumalang & 10 & + & + & Sentra produksi \\
12 & Mojotengah & 8 & + & - & Sentra produksi \\
13 & Garung & & &
\end{tabular}

ekonomi yang tinggi.

Komoditas Padi. Kabupaten Wonosobo merupakan wilayah yang berpotensi dalam menghasilkan komoditas padi. Oleh sebab itu komoditas padi di kabupaten Wonosobo terdapat di hampir semua kecamatan di kabupaten Wonosobo di antaranya adalah kecamatan Wadaslintang, Kepil, Sapuran, Kalibawang, Kaliwiro, Sukoharjo, Selomerto, Kalikajar, Kertek, Wonosobo, Watumalang, Mojotengah dan kecamatan Garung. Hal tersebut dikarenakan wilayah Wonosobo merupakan daerah yang memiliki tanah yang sangat subur, padi yang dikembangkan di daerah ini adalah tanaman padi pada lahan basah dan lahan kering. Keberhasilan dalam panen padi ini selain karena dukungan luas tanam wilayah juga sangat tergantung dengan keberhasilan dalam pengendalian hama.

Tabel 4 ini menyajikan arah pengembangan untuk komoditas padi yaitu melalui pembangunan penggilingan padi dan sentra produksi. Pertimbangan pembangunan industri pengolahan berupa penggilingan padi adalah kecamatan tersebut memiliki jumlah fasilitas sosial dan ekonomi yang tinggi, yang berarti menggambarkan kelengkapan infrastruktur dalam memberikan pelayanan kepada masyarakat.

Pembangunan penggilingan padi untuk komoditas padi unggulan direkomendasikan di kecamatan Kepil dan Kertek.

Penggilingan padi di kecamatan Kepil digunakan untuk menampung produksi dari kecamatan Sapuran, Kalibawang, Kaliwiro dan Wadaslintang. Penggilingan padi di kecamatan Kertek digunakan untuk menampung produksi

Tabel 5. Arah Pengembangan Komoditas Tanaman Jagung

\begin{tabular}{|c|c|c|c|c|c|}
\hline \multirow[t]{2}{*}{ No } & \multirow[t]{2}{*}{ Kecamatan } & \multirow{2}{*}{$\begin{array}{c}\text { Rangking } \\
\text { Skalogram }\end{array}$} & \multicolumn{2}{|c|}{ Keunggulan } & \multirow[t]{2}{*}{ Arah Pengembangan } \\
\hline & & & SS & LQ & \\
\hline 1 & Wadaslintang & 3 & + & + & Sentra produksi \\
\hline 2 & Kepil & 1 & - & + & Industri Pengolahan \\
\hline 3 & Sapuran & 7 & + & + & Sentra produksi \\
\hline 4 & Kalibawang & 14 & + & + & Sentra produksi \\
\hline 5 & Kaliwiro & 5 & + & - & Sentra produksi \\
\hline 6 & Leksono & 13 & + & - & Sentra produksi \\
\hline 7 & Selomerto & 12 & + & - & Sentra produksi \\
\hline 8 & Kalikajar & 6 & + & + & Sentra produksi \\
\hline 9 & Kertek & 2 & - & + & Industri Pengolahan \\
\hline 11 & Watumalang & 9 & - & + & Sentra produksi \\
\hline 12 & Mojotengah & 10 & - & + & Sentra produksi \\
\hline 13 & Kejajar & 11 & + & - & Sentra produksi \\
\hline
\end{tabular}


padi dari kecamatan Kalikajar, Selomerto, Wonosobo, Mojotengah, Garung, Watumalang, dan Sukoharjo.

Komoditas Jagung. Pengembangan komoditas jagung terdapat di kecamatan Wadaslintang, Kepil, Sapuran, Kalibawang, Kaliwiro, Leksono, Selomerto, Kalikajar, Kertek, Watumalang, Mojotengah, dan Kejajar. Sehingga jika dilihat pada gambar peta komoditas tersebut terlihat menyebar di hampir sebagian besar wilayah kabupaten Wonosobo.

Komoditas jagung banyak dijumpai di kecamatan-kecamatan tersebut karena merupakan daerah yang sebagian lahannya adalah berupa lahan kering (dry land) dalam bentuk ladang dan pekarangan. Bentuk produksi dari komoditas ini yaitu dalam pipilan kering.

Arah pengembangan komoditas jagung yaitu industri pengolahan komoditas jagung dibangun di kecamatan Kepil dan Kertek. Pertimbangan dari pemilihan lokasi industri pengolahan di kecamatan Kepil dan Kertek karena kedua daerah itu merupakan daerah penghasil jagung dan memiliki fasilitas pelayanan sosial dan ekonomi yang tinggi.

Industri pengolahan jagung di kecamatan Kepil adalah untuk menampung produksi dari kecamatan Sapuran, Kalibawang, Kaliwiro dan Wadaslintang. Sedangkan industri pengolahan di kecamatan Kertek digunakan untuk menampung produksi jagung dari kecamatan Kalikajar, Selomerto, Leksono, Mojotengah, Watumalang, dan Kejajar.

Berbagai produk turunan komoditas jagung antara lain: tepung maizena, produk ma- kanan seperti keripik jagung dan pop corn. Beberapa produk tersebut memiliki nilai ekonomi lebih tinggi dibandingkan apabila jagung dijual dalam bentuk pipilan mentah.

Komoditas Ubi Kayu. Komoditas ubi kayu relatif tumbuh di kabupaten Wonosobo bagian utara dan selatan, bentuk produksinya adalah dalam bentuk umbi basah. Jika dilihat dari gambar peta, ubi kayu terdapat di kecamatan Kejajar, Garung, Mojotengah, Watumalang, Sukoharjo, Leksono, Selomerto, Sapuran, Kalibawang, Kepil, dan Wadaslintang. Dilihat dari potensi produksi ubi kayu, maka diperlukan industri pengolahan yang mampu menyerap produksi ubi kayu yang dihasilkan menjadi produk makanan yang bernilai tinggi. Untuk itu diperlukan teknologi pengolahan pascapanen dan juga perlu dilakukan pembinaan, penyuluhan dan pengenalan teknologi kepada para petani terutama di kecamatan-kecamatan yang merupakan basis komoditasnya adalah ubi kayu.

Tabel 6 menyajikan arah pengembangan komoditas ketela pohon di kabupaten Wonosobo. Pembangunan industri pengolahan ketela pohon direkomendasikan di kecamatan Kepil dan Garung dengan pertimbangan bahwa kedua kecamatan tersebut merupakan daerah penghasil ubi kayu dan memiliki fasilitas ekonomi dan sosial yang paling tinggi di clusternya.

Sentra industri pengolahan di kecamatan Kepil digunakan untuk menampung produksi ubi kayu dari kecamatan Sapuran, Kalibawang dan Wadaslintang. Sedangkan industri peng-

Tabel 6. Arah Pengembangan Komoditas Tanaman Ubi kayu

\begin{tabular}{clcccc}
\hline No & \multicolumn{1}{c}{ Kecamatan } & Rangking & \multicolumn{2}{c}{ Keunggulan } & Arah Pengembangan \\
& & Skalogram & SS & LQ & \\
\hline 1 & Wadaslintang & 3 & + & + & Sentra produksi \\
2 & Kepil & 1 & - & + & Industri Pengolahan \\
3 & Sapuran & 7 & + & + & Sentra produksi \\
4 & Kalibawang & 14 & + & + & Sentra produksi \\
5 & Leksono & 13 & + & - & Sentra produksi \\
6 & Sukoharjo & 15 & - & + & Sentra produksi \\
7 & Selomerto & 12 & + & - & Sentra produksi \\
8 & Watumalang & 9 & - & + & Sentra produksi \\
9 & Mojotengah & 10 & + & + & Sentra produksi \\
10 & Garung & 8 & - & + & Industri Pengolahan \\
11 & Kejajar & 11 & + & - & Sentra produksi \\
\hline
\end{tabular}


Tabel 7. Arah Pengembangan Komoditas Tanaman Ketela Rambat

\begin{tabular}{llcccc}
\hline No & Kecamatan & Rangking & \multicolumn{2}{c}{ Keunggulan } & Arah Pengembangan \\
& & Skalogram & SS & LQ & \\
\hline 1 & Selomerto & 12 & + & - & Sentra produksi \\
2 & Kalikajar & 6 & + & + & Industri Pengolahan \\
3 & Watumalang & 9 & + & + & Sentra produksi \\
4 & Mojotengah & 10 & + & + & Sentra produksi \\
5 & Garung & 8 & + & + & Industri Pengolahan \\
\hline
\end{tabular}

olahan yang berada di kecamatan Garung digunakan untuk menampung hasil produksi ubi kayu dari kecamatan Kejajar, Mojotengah, Watumalang, Sukoharjo, Leksono, dan Selomerto.

Berbagai produk turunan utama dari komoditas ketela pohon antara lain: tepung tapioka, tepung kanji dan jika dikembangkan lagi dapat menghasilkan produk makanan seperti keripik singkong, kue, makanan ringan, dan lain-lain. Pengolahan ubi kayu menjadi berbagai macam produk turunan tersebut tentunya akan meningkatkan nilai ekonomi dari ubi kayu.

Komoditas Ubi Rambat. Bentuk produksi ubi rambat ini yaitu dalam bentuk umbi basah. Jika dilihat peta komoditas ubi rambat relatif lebih berkembang di kabupaten Wonosobo bagian utara yaitu di kecamatan Kalikajar, Selomerto, Garung, Mojotengah, dan Watumalang. Industri pengolahan komoditas ketela rambat direkomendasikan di kecamatan Kalikajar, dengan pertimbangan kecamatan tersebut merupakan penghasil ubi rambat dan memiliki fasilitas sosial dan ekonomi yang tinggi (Tabel 7).

Industri pengolahan yang direkomendasikan adalah di kecamatan Kalikajar dan Garung. Industri pengolahan yang berada di kecamatan Kalikajar digunakan untuk menampung hasil produksi ubi rambat dari kecamatan Selomerto. Sedangkan industri yang berada di kecamatan Garung digunakan untuk menampung produk- si dari kecamatan Mojotengah dan Watumalang. Berikut ini adalah peta pengembangan komoditas tanaman ketela rambat.

Ketela rambat jika diolah dapat menghasilkan berbagai produk makanan yang bercita rasa tinggi dan bernilai jual lebih tinggi dibandingkan dengan sebelum diolah. Berbagai produk tersebut misalnya keripik ketela rambat, kue, snack, dan makanan ringan lainnya.

Komoditas Kacang-kacangan. Pengembangan komoditas kacang-kacangan dilakukan di kabupaten Wonosobo bagian selatan. Jika dilihat pada peta, daerah-daerah sebagai basis pengembangan komoditas kacang-kacangan antara lain: kecamatan Kepil, Sapuran, Kalibawang, Wadaslintang, dan Selomerto.

Arah pengembangan dari komoditas kacang-kacangan yaitu pembangunan industri pengolahan direkomendasikan di kecamatan Kepil. Industri pengolahan yang direkomendasikan cukup satu karena dirasa cukup untuk menampung seluruh produksi dari daerah-daerah sentra produksi. Berikut ini adalah peta potensi komoditas tanaman kacang-kacangan.

Pertimbangan pembangunan industri pengolahan di kecamatan Kepil adalah karena kecamatan tersebut merupakan salah satu daerah penghasil kacang-kacangan dan memiliki tingkat kelengkapan fasilitas sosial dan ekonomi paling tinggi.

Tabel 8. Arah Pengembangan Komoditas Tanaman Kacang-kacangan

\begin{tabular}{llcccc}
\hline No & Kecamatan & Rangking & \multicolumn{2}{c}{ Keunggulan } & Arah Pengembangan \\
& & Skalogram & SS & LQ & \\
\hline 1 & Wadaslintang & 3 & + & + & Sentra produksi \\
2 & Kepil & 1 & + & + & Industri Pengolahan \\
3 & Sapuran & 7 & - & + & Sentra produksi \\
4 & Kalibawang & 14 & - & + & Sentra produksi \\
5 & Selomerto & 12 & + & + & Sentra produksi \\
\hline
\end{tabular}


Tabel 9. Arah Pengembangan Komoditas Tanaman Sayuran

\begin{tabular}{|c|c|c|c|c|c|}
\hline \multirow[t]{2}{*}{ No } & \multirow[t]{2}{*}{ Kecamatan } & \multirow[t]{2}{*}{ Rangking Skalogram } & \multicolumn{2}{|c|}{ Keunggulan } & \multirow[t]{2}{*}{ Arah Pengembangan } \\
\hline & & & SS & LQ & \\
\hline 1 & Wadaslintang & 3 & + & - & Sentra produksi \\
\hline 2 & Sapuran & 7 & + & + & Sentra produksi \\
\hline 3 & Leksono & 13 & + & - & Sentra produksi \\
\hline 4 & Selomerto & 12 & + & - & Sentra produksi \\
\hline 5 & Kalikajar & 6 & - & + & Sentra produksi \\
\hline 6 & Kertek & 2 & - & + & Industri Pengemasan \\
\hline 7 & Wonosobo & 4 & + & + & Sentra produksi \\
\hline 8 & Watumalang & 9 & + & + & Sentra produksi \\
\hline 9 & Mojotengah & 10 & + & + & Sentra produksi \\
\hline 10 & Garung & 8 & + & + & Sentra produksi \\
\hline 11 & Kejajar & 11 & - & + & Sentra produksi \\
\hline
\end{tabular}

Kacang-kacangan apabila diolah dapat menghasilkan produk yang banyak diminati oleh masyarakat umum. Produk turunan utama dari kacang-kacangan berupa biji kacang dan jika diolah dapat menghasilkan produk makanan seperti snack, kue, selai rasa kacang, permen, dan makanan ringan lainnya.

Komoditas Sayuran. Di kabupaten Wonosobo terdapat sebelas daerah yang berpotensi menjadi lokasi pengembangan komoditas sayuran. Daerah-daerah tersebut di antaranya adalah kecamatan Wadaslintang, Sapuran, Leksono, Selomerto, Kalikajar, Kertek, Wonosobo, Watumalang, Mojotengah, Garung, dan Kejajar. Daerah pengembangan komoditas sayuran unggulan ini membentuk suatu cluster di kabupaten Wonosobo bagian utara.

Arah pengembangan dari komoditas kacang hijau yaitu bahwa pembangunan industri yang akan direncanakan adalah industri penge- masan. Karena sayuran merupakan produk yang biasa dikonsumsi untuk dimasak kembali oleh konsumen, jadi yang dibutuhkan disini adalah usaha packing yang menarik dan yang dapat membuat sayur menjadi lebih tahan lama serta tetap higienis. Sayuran yang di packing dengan menarik dan higienis nilainya akan lebih tinggi dan berpeluang untuk masuk ke pasar-pasar swalayan daripada yang dijual apa adanya tanpa dikemas. Industri pengemasan direkomendasikan di kecamatan Kertek. Pertimbangan pembangunan industri pengolahan di kecamatan Kertek karena kecamatan tersebut merupakan daerah pengembangan komoditas sayuran dan memiliki tingkat fasilitas ekonomi dan sosial yang tinggi.

Komoditas Buah-buahan. Di kabupaten Wonosobo terdapat sebelas daerah yang merupakan daerah pengembangan komoditas tanaman buah-buahan, yaitu kecamatan Wadas-

Tabel 10. Arah Pengembangan Komoditas Tanaman Buah-buahan

\begin{tabular}{clcccc}
\hline No & Kecamatan & Rangking & \multicolumn{2}{c}{ Keunggulan } & Arah Pengembangan \\
& & Skalogram & SS & LQ & Sentra produksi \\
\hline 1 & Wadaslintang & 3 & - & + & Industri Pengolahan dan Pengemasan \\
2 & Kepil & 1 & + & + & Sentra produksi \\
3 & Kalibawang & 14 & + & - & Industri Pengolahan dan Pengemasan \\
4 & Kaliwiro & 5 & + & - & Sentra produksi \\
5 & Leksono & 13 & + & + & Sentra produksi \\
6 & Sukoharjo & 15 & - & + & Sentra produksi \\
7 & Selomerto & 12 & + & + & Sentra produksi \\
8 & Kalikajar & 6 & + & - & Industri Pengolahan dan Pengemasan \\
9 & Watumalang & 9 & + & - & Sentra produksi \\
10 & Mojotengah & 10 & + & - & Sentra produksi \\
11 & Kejajar & 11 & + & - &
\end{tabular}


lintang, Kepil, Kalibawang, Kaliwiro, Leksono, Sukoharjo, Selomerto, Kalikajar, Watumalang, Mojotengah, dan Kejajar. Arah pengembangan dari komoditas buah-buahan yaitu akan terdapat tiga daerah pembangunan industri yang merupakan industri pengolahan maupun industri pengemasan buah-buahan. Melihat sebaran daerah sentra produksi buah-buahan yang cukup banyak maka ditunjuk tiga daerah yang akan dijadikan lokasi industri agar bisa menampung hasil produksi di tiga bagian wilayah yaitu daerah kabupaten Wonosobo bagian utara, barat, dan selatan. Buah-buahan banyak dikonsumsi secara langsung tanpa diolah terlebih dahulu, namun banyak juga produk olahan yang berasal dari buah-buahan yang sering dikonsumsi masyarakat seperti selai, manisan, buah kaleng, permen buah, dan lain-lain. Jadi di sini industri yang direkomendasikan untuk didirikan ada dua jenis yaitu industri pengolahan dan pengemasan.

\section{SIMPULAN}

Pertama, produktivitas tertinggi dalam pertanian di kabupaten Wonosobo adalah tanaman sayuran yang mencapai 176.981 ton dengan luas panen 13.383 ha; Kedua, komoditas tanaman pangan yang dapat dikembangkan di tiap kecamatan adalah komoditas unggulan dan potensial yaitu komoditas tanaman pangan yang memiliki keunggulan kompetitif dan komparatif atau salah satunya. Komoditas-komoditas tanaman pangan yang dapat dikembangkan di tiap kecamatan di kabupaten Wonosobo adalah di kecamatan Wadaslintang adalah padi, jagung, ubi kayu, kacang-kacangan, sayuran, dan buah-buahan. Kecamatan Kepil adalah padi, jagung, ubi kayu, kacangkacangan, dan buah-buahan. Kecamatan Sapuran adalah padi, jagung, ubi kayu, kacang-kacangan, dan sayuran. Kecamatan Kalibawang adalah padi, jagung, ubi kayu, kacang-kacangan, dan buah-buahan. Kecamatan Kaliwiro adalah padi, jagung, dan buah-buahan. Kecamatan Leksono adalah jagung, ubi kayu, sayuran, dan buah-buahan. Kecamatan Sukoharjo adalah padi, ubi kayu dan buah-buahan. Kecamatan Selomerto adalah padi, jagung, ubi kayu, ubi jalar, kacang-kacangan, sayuran, dan buahbuahan. Kecamatan Kalikajar adalah padi, jagung, ubi jalar, sayuran, dan buah-buahan. Kecamatan Kertek adalah padi, jagung dan sayuran. Kecamatan Wonosobo adalah padi dan sayuran. Kecamatan Watumalang adalah padi, jagung, ubi kayu, ubi jalar, sayuran dan buah-buahan. Kecamatan Mojotengah adalah padi, jagung, ubi kayu, ubi jalar, sayuran dan buah-buahan. Kecamatan Garung adalah padi, ubi kayu, ubi jalar dan sayuran. Kecamatan Kejajar adalah jagung, ubi kayu, saturan dan buah-buahan. Ketiga, berdasarkan hasil analisis Skalogram diketahui kecamatan yang memiliki kelengkapan infrastruktur tinggi adalah kecamatan Kepil, Kertek, Wadaslintang, Wonosobo, dan Kaliwiro. Sedangkan kecamatan yang memiliki jumlah unit fasilitas umum rendah yaitu kecamatan Kejajar, Selomerto, Leksono, Kalibawang, dan Sukoharjo. Keempat, komoditas tanaman pangan unggulan apabila dilakukan pemetaan akan terlihat bahwa telah terjadi pengelompokan wilayah, dari cluster komoditas tersebut akan diarahkan pengembangannya, yaitu dengan pembangunan sentra produksi dan sentra industri pengolahan. Industri pengolahan digunakan untuk menampung hasil produksi dari daerah-daerah sentra produksi dan mengolahnya menjadi produk-produk yang memiliki nilai jual lebih tinggi. Daerah yang akan menjadi sentra produksi padi adalah kecamatan Wadaslintang, Kepil, Sapuran, Kalibawang, Kaliwiro, Sukoharjo, Selomerto, Kalikajar, Kertek, Wonosobo, Watumalang, Mojotengah, dan kecamatan Garung dengan lokasi penggilingan padi di kecamatan Kepil dan Kertek. Sentra produksi komoditas jagung adalah di kecamatan Wadaslintang, Kepil, Sapuran, Kalibawang, Kaliwiro, Leksono, Selomerto, Kalikajar, Kertek, Watumalang, Mojotengah, dan Kejajar. Sedangkan industri pengolahan jagung direkomendasikan di kecamatan Kepil dan Kertek. Untuk komoditas ubi kayu sentra produksinya terdapat di kecamatan Kejajar, Garung, Mojotengah, Watumalang, Sukoharjo, Leksono, Selomerto, Sapuran, Kalibawang, Kepil dan Wadaslintang. Sedangkan industri pengolahan ubi kayu didirikan di kecamatan Kepil dan Garung. Kecamatan Kalikajar, Selo- 
merto, Garung, Mojotengah dan Watumalang merupakan sentra produksi ubi rambat dan kecamatan Kalikajar dan Garung menjadi lokasi industri pengolahannya. Untuk sentra produksi kacang-kacangan terdapat di kecamatan Kepil, Sapuran, Kalibawang, Wadaslintang dan Selomerto. Industri pengolahan komoditas kacangkacangan yang direkomendasikan adalah di kecamatan Kepil. Kecamatan Wadaslintang, Sapuran, Leksono, Selomerto, Kalikajar, Kertek, Wonosobo, Watumalang, Mojotengah, Garung dan Kejajar merupakan daerah yang ditunjuk sebagai sentra produksi sayuran dan industri pengemasannya terdapat di Kecamatan Kertek. Yang terakhir adalah komoditas buah-buahan, sentra produksinya adalah di kecamatan Wadaslintang, Kepil, Kalibawang, Kaliwiro, Leksono, Sukoharjo, Selomerto, Kalikajar, Watumalang, Mojotengah, dan Kejajar. Sedangkan Kepil, Kaliwiro, dan Watumalang adalah tempat industri pengolahan dan pengemasannya.

\section{DAFTAR PUSTAKA}

Anriquez, G., and Kostas Stamoulis. 2007. Rural Development and Poverty reduction: is Agriculture Still the Key?' Electronic Journal of Agricultural and Development Economics, 4(1), 5-46.

Arsyad, Lincolin. 1999. Pengantar Perencanaan Pembangunan Ekonomi Daerah, Edisi Pertama. Yogyakarta: BPFE.

Ashby, L.D. 1964. The Geographical Redistribution of Employent: An Examination of the Elements of Change. Survey of Current Business. 44; hal. 13-20

Azis, I.J., 1994, Ilmu Ekonomi Regional dan Beberapa Aplikasinya di Indonesia. Jakarta: LPFE-UI.

Beck, Roger J. dan William McD. Herr. 1990. Employment Linkages from A Modified Share Analysis: An Illinois Example. The Review of Regional Studies. 20; hal. 38-45

Biro Pusat Statistik. 2010. Jawa Tengah dalam Angka 2010. Jawa Tengah: BPS.
Biro Pusat Statistik, 2010. Wonosobo dalam Angka 2010. Wonosobo: BPS.

Blakely, EJ. 1994. Planning Local Economic Development Theory and Practice, $2^{\text {nd }}$ ed., Thousand Oaks: SAGE Publications.

Center for Business Research. 1997. Key Arizona Economic Activities identified" Arizona State University's Monthly Newsletter on the Arizona Economy, Vol. 44. Number 9, 1-6.

Creamer, DB. 1943. Shift of Manufacturing Industries. Industrial Location and National Resources. Washington, D.C.: U.S. National Resources Planning Board.

Djaenudin, D., Sulaeman dan A. Abdurachman, 2002. Pendekatan Perwilayahan Komoditas Pertanian Menurut Pedo-Agroklimat di Kawasan Timur Indonesia. Jurnal Litbang Pertanian 21(1), 1-10.

Djojohadikusumo, S. 1994. Perkembangan Pemikiran Ekonomi: Dasar Teori Ekonomi, Pertumbuhan dan Ekonomi Pembangunan. Jakarta: Penerbit PT. Pustaka LP3ES.

Esteban, J. 2003. Regional Convergence In Europe and the Industry Mix: a Shiftshare Analysis. Regional Science and Urban Economics 30 (2003) 353-364.

Hanham, R.Q and Shawn, B. 2000. Shift Share Analysis and Changes in Japanese Manufacturing Employment. Growth and Change, Vol. 31 (Winter) 108-123

Hazell, P., 2007. Transformations in Agriculture and Their Implications for Rural Development. Electronic Journal of Agricultural and Development Economics 4(1), 4765.

Hirschman, A.O. 1958. The Strategy Of Economic Development in Developing Countries. New Haven, Connecticut, USA: Yale University Press.

Hoover, E.M. 1984. An Introduction to Regional Economics, 2nd ed. New York: Knopf. 
Kompas. 2008. Kebijakan Orde Baru Belajar dari Pembangunan Pertanian Soeharto. Kompas [31 Januari 2008].

Perroux, Francois. 1970. Economic Space: Theory and Applications. Quarterly Journal of Economics 64: 89-104.

Riyadi dan Deddy Supriady Brantakusumah. 2004. Perencanan Pembangunan Daerah: Strategi Menggali Potensi dalam Mewujudkan Otonomi Daerah. Jakarta: PT. Gramedia Pustaka Utama.

Soepono, Prasetyo. 1993. Analisis Shift-Share: Perkembangan dan Penerapan. Jurnal Ekonomi dan Bisnis Indonesia. 8(1), 43-54.

Stringer, R., and Prabhu Pingali. 2004. Agriculture's Contributions to Economic and Social Development. Electronic Journal of Agricultural and Development Economics 1 (1), 1-5.

Sudaryanto, T., dan I Wayan Rusastra. 2006. Kebijakan Strategis Usaha Pertanian dalam Rangka Peningkatan Produksi dan
Pengentasan Kemiskinan. Jurnal Litbang Pertanian, 25(4), 115-122.

Sukirno, S. 1985. Ekonomi Pembangunan - Proses, Masalah dan Dasar Kebijakan, Jakarta: LP3ES-UI dengan Bina Grafika.

Sjafrisal. 1997. Pertumbuhan Ekonomi dan Ketimpangan Regional Wilayah Indonesia Bagian Barat. Prisma Nomor 3. Jakarta: LP3ES.

Syafruddin, Agustinus, N, Kairupan, A dan J. Limbongan. 2004. Penataan Sistem Pertanian dan Penetapan Komoditas Unggulan Berdasarkan Zona Arkeologi di Sulawesi Tengah. Jurnal Litbang Pertanian, 23(2), 61-67.

Temenggung, S.A. 1999. Paradigma Ekonomi Wilayah: Tujuan Teori dan Praktis Ekonomi Wilayah dan Implikasi Kebijakan Pembangunan, dalam BTS.

Todaro, Michael P. 2003. Economic Development, Eight Edition. United Kingdom: Pearson Education Limited. 